\title{
Marketing Communication Strategy Using Direct Marketing For Start-Up Fashion Brand Teemochi
}

\author{
Yohanes Dicky and Alvanov Z. Mansoor
}

\begin{abstract}
Teemochi is a fashion brand that values comfort the most and expect users to get a deep feeling of comfort by using Teemochi products. Teemochi, which just arrived in the community in October 2019, has a number of problems with brand awareness and relatively little sales. Therefore, the aim of this research is to create a marketing communication strategy that increases Teemochi brand awareness and how that marketing strategy can also affect sales.
\end{abstract}

This study uses internal and external analysis to know the conditions and look for sources of problems that exist in the Teemochi. In internal analysis, this research uses Resource Based View Analysis which using Segmenting, targeting, and positioning (STP) internal data and Marketing Mix before. In external Teemochi analysis uses Customer Analysis, Competitor Analysis and Industry Analysis using Porter's 5 Forces. After knowing the condition and the problems faced by Teemochi, it is known that promotion is the main problem that will be discussed further to help Teemochi in general.

Therefore, recommendations that can be given in this study include Instagram Advertising, Paid promotion, Video marketing and 17 other promotional strategies. The direct marketing method on social media especially through Instagram is the chosen method so that the existing marketing strategy can increase Teemochi brand awareness and influence also to increase Teemochi sales.

After all analysis and strategy development have been outlined, a timeline and budgetary budget are also made to realize all marketing strategies that have been formed. All strategies that have been made will lead and lift one value from Teemochi itself, namely "Comfy" with the slogan \#ComfyEveryday and \#ComfyCanBeFun.

Index Terms - Marketing Mix, Promotions, Direct Marketing, Instagram.

\section{INTRODUCTION AND RESEARCH OBJECTIVES}

The rapid development of technology, especially the internet, also influences the ease of dissemination of trend information in the world, especially in Indonesia. The total of internet users in Indonesia-which is also an active social media users- according to Hootsuite and WeAreSocial are Indonesia itself has 150 million internet users, which makes the dissemination of information and trends faster. Because of the internet, social media began to develop, One of the example is Instagram. Indonesia ranked fourth as the most Instagram users in the world. ${ }^{[1]}$

A few years back, a new fashion trend began to exist in Indonesia, which is streetwear fashion, that was influenced by the sneakers trend. The development of the streetwear fashion is because of the easy distribution of information through

Published on April 09, 2020.

Yohanes Dicky, Institut Teknologi Bandung, Indonesia.

(Yohanes Dicky@sbm-itb.ac.id)

Alvanoz Zpalanzani Mansoor, Institut Teknologi Bandung, Indonesia.

(alvanov.mansoor@itb.ac.id) social media. Data from the streetwear impact report says $92.04 \%$ respondents get streetwear information from social media namely Instagram. From the report, there is also a data that said that $57.47 \%$ percent of respondents chose comfortable clothing in streetwear. ${ }^{[2]}$

By knowing the trend of streetwear also the large market in Indonesia and the use of Instagram in Indonesia, the Teemochi fashion brand was formed, which sells Streetwear with the core value of "Comfy".

\section{A. Statement of the Problem}

After Teemochi's operation, several problems were found such as: no warehouse, poor coordination, too many product stock, $75 \%$ sales only from inner circle, Slow followers growth, does not have an internal illustrator, and also the brand that is still new. Of all the business issues that exist, New brand is a business issue that will be raised at this study.

\section{B. Research Objectives}

The objective of this final project is to analyze Teemochi's marketing communication strategy on the social media platform in order to increase brand awareness through the core value offered by Teemochi to followers which results in increasing sales of Teemochi products.

\section{RESEARCH METHODOLOGY}

Research methods used in this study are literature studies, analytical management tools and also data that support this study. Theories of literature studies can include books, websites and journals. In analytical management tools which will dissect and analyze both sides internal and external companies in this final project will use resource based view analysis, competitor analysis, customer analysis, industry analysis and business strategy formulation and solutions. Supporting data will use the results of the interview to customers and also experts in the field of retail fashion. Secondary data obtained from BEKRAF or BPS or relevant survey results to assist this study.

\section{EXTERNAL ANALYSIS}

\section{A. Customer Analysis}

The Customer Analysis aims to find out the customer behavior of young Indonesians in shopping for fashion products. The method used in the final Customer Analysis project uses the in-Depth Interview. Interview questions are categorized into 2 parts, they are general questions and specific questions aimed at Instagram and online shopping and the specific questions also refer to 7P, namely Product, Place, Price, Promotions, Physical Evidence, People, and Process. Answers from general questions are expected to know the habits of consumers shopping for fashion products in general. Through this general question it is known that, in shopping for 
fashion products respondents do not only use the online Teemochi. platform, but conventional ways or shop directly to the offline store are still rife by respondents for certain reasons. The respondent also said to shop online they prefer marketplaces such as Shopee and Tokopedia because of the convenience of shopping with the advantages of existing features. On the results of general questions it is also known that all respondents prefer to use Instagram social media which indeed if explored further, Indonesia will This is ranked 4th as an active Instagram user in the world. ${ }^{[1]}$ The diagram that was considered highly visual by respondents with all its ease made all respondents also said that the most effective social media to sell fashion products at this time were Instagram. Instagram and Youtube is also the respondent's answer to a platform that advertises fashion products very often. The Instagram Story feature that is currently used by respondents and other young Indonesians is the promotion media most frequently seen by respondents for fashion products. The end of the interview on this general question closes with the answers of all respondents. to find out what the biggest factor that respondents choose in making a decision to buy a fashion product, respondents' answers also vary, but for respondents who love and shop more frequently online then the price and convenience of shopping are the priority, for respondents who prefer and often shop Fashion products through the offline store prefer material and cutting a fashion product.

Respondent data that will be used for this study, namely through general questions obtained conclusions, both online and offline are still used by all respondents in purchasingfashion products, Instagram is a social media that is needed if asked with fashion products, E-Commerce such as Shopee and Tokopedia is also often used by respondents to buy fashion products because there are transactions as well as vouchers in E-Commerce, Price, Ease of Transaction, Materials and Cutting fashion products are factors related to the need to buy fashion products.

After the general questions given to the respondents, specific questions about Instagram and the Online Store began. Specific questions about Instagram and the Online Shop were made with reference to the 7P marketing Mix, using aspects of Product, Place, Price, Promotions, Physical Evidence, People, and Process. The answers to specific questions about Instagram and the Online Store will also be used as supporting data for the formulation of STP and the Teemochi marketing mix strategy.

\section{B. Competitor Analysis}

Competitor analysis in this study is more about the marketing mix that is used 4P (Product, Price, Place and Promotions) by competitors, the media strategy in terms of marketing, and the selling strategy used by competitors. Competitor Analysis is useful for reflecting on competitors, what are competitors do and what strategies they do. Each competitor variable becomes a reference so that Teemochi can learn from what has been done by competitors who will later become STP (Segmenting, Targeting, Positioning) and Marketing Mix Teemochi here after. This competitor analysis focuses fully on the variable promotions which are also going forward as a marketing strategy reference that will be used by

\section{Industry Analysis (Porter's 5 Forces)}

Porter's 5 Forces model is a model for analyzing industry and developing business strategies or competitive environments. Porter's Five forces contains bargaining power of buyers, bargaining power of supplier, threat of new entrants, threat of substitutes product, and rivalry among existing competitors. ${ }^{[3]}$



Figure 1: Porter Five Force Analysis Result

The following is a business situation with Porter 5 forces in the fashion industry.

- Bargaininng Power of Buyers/ Buyers' Power The bargaining power of buyers in this industry is high because clothing is one of the main needs of humans. The taste and design for a design or product variant for each buyer are different. Having more attention to satisfy buyers is a must that must be planted in a brand because disappointed customers most likely will not want to buy again. Recommendations from customers are also needed for this industry, for example, customers who like products in this industry will post on their social media that will have an impact on sales and brand awareness of a brand in this industry. Therefore, bargaining the power of buyer or customer is very high.

- Bargaininng Power of Suppliers/ Suppliers' Power Bargaining power of suppliers for the fashion industry is categorized as low because basically this industry is a major human need. Thus, the raw materials used are also widely offered in the market and have a variety of types and varying prices

- Thread of New Entrants

The category for threads of new entrants in the fashion industry is medium. The variety of raw materials and services for making industrial fashion make the business in this industry easy to enter. Relatively inexpensive prices are also another factor. Nevertheless, quite large capital is needed to run this business because this kind of industry has a fast rhythm or also often called fast moving goods. It is because usually every month there will be a new product to launch for a brand existence.

- Threat of Substitute Product or Services Threat of substitute product or services is categorized as high because there are many substitutions for the industry, especially T-Shirts. 
Examples of substitution in this industry are the and internal weaknesses, is actually in a dangerous position. In presence of other industries with other brands or fact, the company may have to struggle to survive, or merge, can be replaced with jackets, socks, shoes and rationalize, declare bankruptcy or choose to be liquidated. [4] other fashion items.

- Rivalry Among Existing Competitor The following TOWS matrix was created as a strategy for the future.

The development of online shops at this time also affect the ease of the entire community to open the way to start selling. With facilities like that, competitors in this industry are also very many with rapid growth too. The competition in this industry also varies from the uniqueness of each brand, and also the competitive prices. Therefore, the category for rivalry among existing competitors is categorized as high.

After describing each of the variables in this Porter 5 Forces analysis, it can be concluded that the competition in the fashion industry is high. With this analysis, also can see the opportunities as well as the threats faced in this fashion industry and can be anticipated in the future made into a strategy to be able to survive in the fashion industry. The amount of power from the buyer is also an opportunity that if used properly will become an advantage in this industry. Raw materials that are easily obtained and varying prices can also be used as an opportunity in the fashion industry because they can get a greater profit margin. A lot of product substitutions as well as many similar competitors and also the ease of new entrants in this industry can also be a challenge in the fashion industry. To survive in this industry, also can use the opportunities that exist to be processed into in a strategy. Uniqueness is also the key to being able to survive in this fashion industry.

\section{TOWS MATRIX}

TOWS analysis is a tool which is used to generate, compare and select strategies. The TOWS Matrix is aimed at developing strategic options from an external-internal analysis and is a practical tool, particularly in the fields of business administration and marketing. The TOWS strategy matrix summarizes the matching tools that are important in helping companies develop four types of strategies, namely the SO (Strengths-Opportunities) strategy, the WO (WeaknessOpportunities) strategy, the ST (Strengths-Threaths) strategy and the WT (Weakness-Threats) strategy. Matching key external and internal factors is a difficult part of developing the TOWS Matrix and requires good judgment. ${ }^{4]}$

The SO strategy uses the company's internal strengths to take advantage of external opportunities. If the company has a big weakness, the company will try hard to overcome it and make it a strength. If faced with a major threat, an organization will try to avoid it so that it can focus on opportunities. ${ }^{[4]}$ The WT strategy aims to correct weaknesses by exploiting external opportunities. Sometimes great external opportunities exist, but a company's internal weaknesses make it unable to take advantage of those opportunities. ${ }^{[4]}$ The ST Strategy uses the company's strengths to avoid or reduce the impact of external threats. This does not mean that strong organizations always face frontal threats in the external environment. ${ }^{[4]}$ The WT strategy is a defensive tactic aimed at reducing internal weaknesses and avoiding external threats. An organization which is faced with various external threats

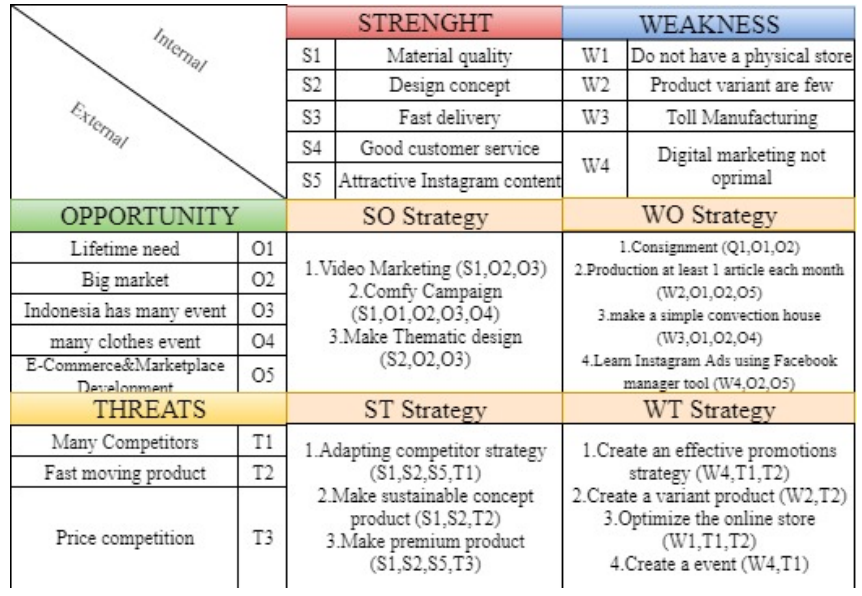

Fig. 1. Teemochi TOWS Matrix

\section{CONCLUSION}

Teemochi which is a new fashion brand has a number of problems faced, one of which is the lack of people's recognition of the brand itself. Resources based view is for sees company resources (tangible and intangible), and determine its ability to have a sustainable competitive advantage when compared to competitors. The resources must be heterogeneous and also immobile and are resources that are VRIO (Value, Rarity, Imitability, Organization) that will produce competitive advantages. After knowing the resources, it is known that Teemochi has sufficient resources to create sustained competitive advantage in the fashion industry such as intellectual properties, privilege with the tailor, and the comfy brand value. The resources with sustained competitive advantage attribute used to make a strategy for Teemochi.

External analysis is used to choose the suitable marketing strategies for Teemochi, through Industry Analysis using Porter's 5 Force, Customer Analysis and Competitor Analysis. Industry Analysis uses Porter's 5 Force to find out how the situation in the fashion industry. Customer Analysis uses InDepth Interview to find out the customer behavior of young Indonesian people in shopping activities for fashion products. Competitor Analysis aims to compare Teemochi to competitors, what competitors have done and what strategies competitors have done with the 4P approach (Product, Price, Place, and Promotions).

After finding the problem, the third chapter has built Business Strategy Formulation by TOWS Matrix, formulating a new STP and Marketing Mix (7P). In order to choose the right marketing strategy and to also increase sales, this research will use marketing communication methods by direct marketing using social media Instagram.

Therefore, these are the strategies that is expected to answer this study:

1. Marketing strategies for Teemochi to increase brand awareness are

- Instagram Ads

- Endorsement(Instagramer/Cellebrity/Celebgra 
$\mathrm{m} /$ Youtuber)

- Brand Collaborations

- Video Marketing (New Product, Value, Story Telling, Soft Selling)

- Make a masterpiece product (Premium)

- Develop Technology Promotions example using AR or Barcode

- Join Big Event

- Develop Teemochi Website

- Discount Voucher 10\% - 25\% For Signing up Website Teemochi

- Special Day Promo

- Payday Promo

- Bundling Promo

- Games Promo

- Clearance Sale

- Free Shipping

- Giveaways

- Special Box

- Attractive Content (Information, Discussion, Feeds Style and Theme, promotions Content)

- Start Build an Offline Store

- Consignment

2. With Direct Marketing method using Social Media which also uses the Promotions strategy as described above, Teemochi believes that the strategy used will affect sales. The key of the strategy affect for the sales is the number of followers, visit profile, reach and impression of the Instagram Ads, number of visit on website Teemochi, database user and engagement rate.

\section{REFERENCES}

[1] Statista. (2019). Statistics. Retrieved from Statista.com: Https://www.statista.com/statistics/578364/countries-with-mostinstagram-users/

[2] Strategyand.hypebeast.com. (2019). Strategyand.hypebeast.com. Retrieved from Strategyand.hypebeast.com: http://strategyand.hypebeast.com/streetwear-report-social-media instagram

[3] Porter. (2008). The Five Competition Forces that Shape Strategy. Boston: Harvard.

[4] David, F. (2004). Manajemen Strategis : Konsep-Konsep edisi sembilan. Jakarta: PT Indeks.

[5] Koekemoer, L. (2004). Marketing Communications. Lansdowne: Juta Academic. 


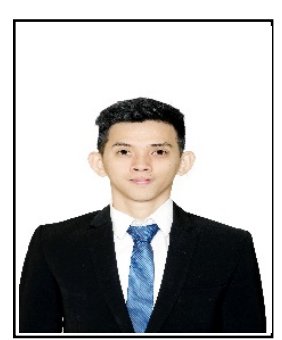

Yohanes Dicky was born on May 09, 1993

in Lampung, Indonesia. He graduated from Maranatha Christian University in 2016 majoring in Information Technology. He continued his post-graduate in Masters of Business Administration at the Bandung Institute of Technology, Indonesia, and graduated in 2020. Yohanes Dicky is currently an entrepreneur in the fashion, photography and videography Industry.

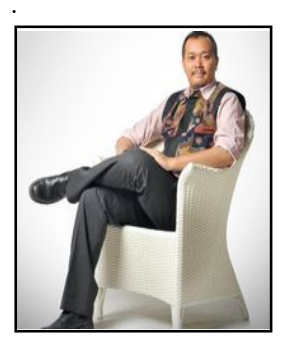

Alvanov Z. Mansoor was born in November 27, 1974 in Bandung, Indonesia. $\mathrm{He}$ completed his doctoral program in Institut Teknologi Bandung majoring in Art and Design studies in 2012 after graduated from Master of Management program, Telkom University in 2005. His exeprtise in research are cultural studies, media studies, visual storytelling, and creative business. Dr. Mansoor, is currently works as lecturer, researcher, boardgame designer, and creative business and visual storytelling consultant. Dr. Mansoor is eager to contribute in cross and multidiscipline studies and various creative projects. 